\title{
M2 Muscarinic acetylcholine receptor modulates rat airway smooth muscle cell proliferation
}

\author{
Fabiola A Placeres-Uray, Christopher A Febres-Aldana, Ruth Fernandez-Ruiz, Ramona Gonzalez de Alfonzo,
} Itala A Lippo de Becemberg and Marcelo J Alfonzo*

\begin{abstract}
Airways chronic inflammatory conditions in asthma and COPD are characterized by tissue remodeling, being smooth muscle hyperplasia, the most important feature. Non-neuronal and neuronal Acetylcholine acting on muscarinic receptors (MAChRs) has been postulated as determinant of tissue remodeling in asthma and COPD by promoting proliferation and phenotypic changes of airway smooth muscle cells (ASMC). The objective was to evaluate proliferative responses to muscarinic agonist as carbamylcholine (Cch) and to identify the MAchR subtype involved. ASMC were isolated from tracheal fragments of Sprague-Dawley rats by enzymatic digestion. Proliferation assays were performed by MTS-PMS method. Viability was confirmed by trypan blue exclusion method. Mitogens as, epidermal growth factor (EGF), Tumor necrosis factor-alpha (TNF-a) and fetal bovine serum (FBS) increased ASMC proliferation $(p<0.05, \mathrm{n}=5)$. Cch alone increased ASMC proliferation at 24 and 48 hrs. However, combination of Cch with other mitogens exhibited a dual effect, synergistic proliferation effect in the presence of EGF $(5 \mathrm{ng} / \mathrm{mL})$ and $5 \% \mathrm{FBS}$ and inhibiting the proliferation induced by $10 \% \mathrm{FBS}$, EGF $(10 \mathrm{ng} / \mathrm{mL})$ and TNF-a $(10 \mathrm{ng} / \mathrm{mL})$. To determine the MAChR subtype involved in these biological responses, a titration curve of selective muscarinic antagonists were performed. The Cch stimulatory and inhibitory effects on ASCM proliferation was blocked by AF-DX-116 ( $\mathrm{M}_{2} \mathrm{AChR}$ selective antagonist), in greater proportion than 4-DAMP $\left(\mathrm{M}_{3} \mathrm{AChR}\right.$ selective antagonist), suggesting that the modulation of muscarinic agonist-induced proliferation is $M_{2} A C h R$ mediated responses. Thus, $M_{2} A C h R$ can activate multiple signal transduction systems and mediate both effects on ASMC proliferation depending on the plethora and variable airway microenvironments existing in asthma and COPD.
\end{abstract}

Keywords: Airway smooth muscle, Muscarinic receptors, Carbamylcholine, ASMC inhibition

\section{Background}

Chronic inflammatory conditions of the airways are usually associated with the development of structural changes of the airways; a phenomenon commonly described as airway remodeling. This process is seen in both asthma and Chronic Obstructive Pulmonary Disease (COPD), albeit the nature, localization and extent of the remodeling are variable [1-4]. Airway remodeling is progressive and the degree of structural changes correlates with disease severity [4]. In this sense, the Airway Smooth Muscle Cells (ASMC) hyperplasia has been postulated as the main mechanism of airway smooth muscle thickening $[5,6]$.

ASMC are multifunctional cells that have high phenotypic plasticity. These cells can shift between different

\footnotetext{
* Correspondence: hmag5@hotmail.com

Sección de Biomembranas, Instituto de Medicina Experimental, Facultad de Medicina, Universidad Central de Venezuela (U.C.V), Caracas, Venezuela
}

phenotypes depending on the stimulation conditions. Accordingly, mitogenic factors can induce the reversible transition to "synthetic-proliferative" phenotype, characterized by high capacity for cell proliferation and secretion [7]. Several mediators, such as growth factors, cytokines, extracellular matrix components, and G protein-coupled receptors (GPCR) agonists have been found in bronchoalveolar lavage fluid of asthmatics. Among the mediators identified include epidermal growth factor (EGF) and tumor necrosis factor-alpha (TNF- $\alpha$ ) [8] and acetylcholine [9].

EGF binds to receptors with intrinsic tyrosine kinase activity [10]. All EGF receptor (EGFR) subtypes are express by ASMC. However, that exerts its effect by acting on the family 1 and $2[10,11]$. Furthermore, this growth factor has been shown as the most potent for ASMC proliferation stimulation. EGFR activation in ASMC triggers mitogenic pathways through p21Ras and PI3-K,

\section{()

(C) 2013 Placeres-Uray et al.; licensee BioMed Central Ltd. This is an open access article distributed under the terms of the Creative Commons Attribution License (http://creativecommons.org/licenses/by/2.0), which permits unrestricted use, distribution, and reproduction in any medium, provided the original work is properly cited. 
resulting in phosphorylation at serine and threonine residues of several transcription factors by mitogen-activated protein kinases (MAP kinases). Thus, DNA synthesis is promoted and initiates the cell cycle $[10,12]$.

The biological effects of TNF- $\alpha$ are mediated through two receptors of similar affinity (TNF-R1, CD120a; 55-kd and TNF-R2, CD120b, 75-kD) [13]. In experimental models have been demonstrated their contribution to chronic inflammation and airway hyperresponsiveness mediated by TNF-R1 [14-16]. ASMC express both TNF-R subtypes [15], whose stimulation induces an increase of proliferation either directly or through other mediators [17]. In this sense, TNF- $\alpha$ can induce MAPK pathway activation including ERKs, p38 MAPK and JNK $[12,15,16]$.

Acetylcholine (Ach) is agonist of muscarinic receptors (MAchRs) that traditionally associated with airway smooth muscle contraction and mucus secretion. Recently it has been postulated as determinant of bronchial remodeling [18]. There are two sources of Ach in the airways: 1) neural, provided by parasympathetic fibers, from vagal nerve and 2) non-neural, from airway epithelium and inflammatory cells present in the chronic inflammation process, currently found in asthma [19]. ASMC express two sub-types of MAChRs: Muscarinic receptor type 2 $\left(\mathrm{M}_{2} \mathrm{AChR}\right)$ and muscarinic receptor type $3\left(\mathrm{M}_{3} \mathrm{AChR}\right)$, whose activation promote synthetic functions, proliferation and phenotypic changes depending on stimulation conditions [19-21]. ASMC proliferation induced by ACh is reversed by the muscarinic antagonists, such as tiotropium bromide [22]. ACh and others agonists of GPCR are not able by themselves to stimulate ASMC proliferation, but enhance the action of growth factors by different signal pathways [23]. However, the results differ between different animal models. Thus, the aim was to study in rat ASMC, the proliferative responses to a muscarinic agonist such as carbamylcholine ( $\mathrm{Cch}$ ), and to establish the MAChR subtype involved. In addition, to evaluate as Control, the classic mytogenic responses induced by fetal bovine serum (FBS), EGF and TNF- $\alpha$. A preliminary description of this work has been reported [24].

\section{Methods}

ASMC were obtained from tracheas of female SpragueDawley rats (12-14 weeks, weighing between 300-350 g) from animal facility of the Instituto de Medicina Experimental (I.M.E) of the Universidad Central de Venezuela (U.C.V). The animals were maintained according to international standards for animal care and experimental protocol was approved by the Bioethics Committee of I.M.E.

\section{Isolation and culture of rat airway smooth muscle cells}

Primary cultures of rat ASMC were established as previously reported [25-27]. Rat trachea was dissected in ice-cold phosphate- buffer saline (PBS) solution, $\mathrm{pH} 7.4$ (composition in g/dL: $0.2 \quad \mathrm{KH}_{2} \mathrm{PO}_{4}, \quad 0.8 \mathrm{NaCl}, 1.15$ $\mathrm{Na}_{2} \mathrm{HPO}_{4}$ ). The epithelium was removed, and muscle were gently separated from underlying connective tissue in small bundles, which were placed in digestion solution (Ringer plus $\mathrm{Ca}^{2+}$ ) containing $4 \mathrm{mg} / \mathrm{mL}$ collagenase II (Worthington $\left.{ }^{\circ}, \mathrm{UK}\right)$ and $0.6 \mathrm{U} / \mathrm{mL}$ dispase (Gibco ${ }^{\oplus}, \mathrm{USA}$ ) by $50-60 \mathrm{~min}$ at $37^{\circ} \mathrm{C}$ under $5 \% \mathrm{CO}_{2}$ Atmosphere. The cell suspension was centrifuged at $500 x g$ by $15 \mathrm{~min}$. Cell suspensions and explants were separately incubated in $25-\mathrm{cm}^{2}$ flasks at $37^{\circ} \mathrm{C}$ in a humidified atmosphere of $5 \%$ CO2 for 16-24 days (incubator NUAIRE ${ }^{\mathrm{TM}}$ ). The cells were cultured in Dulbecco's modified Eagle's medium/F-12 (DMEM/F-12; Gibco ${ }^{\circ}$, USA) supplemented with 10\% FBS (Gibco ${ }^{\circ}$, USA), 1\% L-Glutamine (Gibco ${ }^{\oplus}$, USA), $2 \%$ penicillin/streptomycin (Gibco ${ }^{\circ}$, USA), 2\% amphotericin (Gibco ${ }^{\circ}$, USA) and were passaged when confluent using trypsin/ EDTA $(0.5 \mathrm{~g} / \mathrm{L}$ porcine trypsin, $0.2 \mathrm{~g} / \mathrm{L}$ EDTA, $4 \mathrm{Na} / \mathrm{L})$ of Hanks' balanced salt solution (HBSS); Sigma ${ }^{\circ}$, USA. Cells between passages 3 and 7 were used for all experiments.

\section{Proliferation assays}

ASMC proliferation was estimated by the nonradioactive method (MTS-PMS assay) based on the formation of tetrazolium salts [28] using, CellTiter $96^{\circ}$ AQueous (Promega ${ }^{\circledR}$, USA). A fixed number of cells were seeded onto 96 wells plates. After $24 \mathrm{hrs}$, culture medium was changed by medium without FBS to equilibrate cell cycle in $G_{0} / G_{1}$ phase. After $12-24 \mathrm{hrs}$, cells were incubated at $37^{\circ} \mathrm{C}$ and $5 \% \mathrm{CO}_{2}$ with solution containing the treatment according each experimental conditions using the following compounds: AF-DX-116 (Tocris ${ }^{\circ}$, USA), 4-DAMP (Tocris ${ }^{\oplus}$, USA), carbamylcholine chloride (Cch; Sigma ${ }^{\circ}$ USA), human recombinant EGF (Chemicon International ${ }^{\circ}, \mathrm{USA}$ ), rat recombinant TNF- $\alpha$ (Chemicon International ${ }^{\odot}$, USA)]. After, the exposure time finished, $100 \mu \mathrm{L}$ of medium plus $10 \mu \mathrm{L}$ MTS [3-(4,5-dimethylthiazol-2yl)-5-(3-carboxymethoxyphenyl)-2-(4-sulfophenyl)-2H-tetrazolium]-PMS [Phenazine Methosulfate]/well, and incubated for additional $90 \mathrm{~min}$. The cell proliferation were determinated measuring optical density (OD) at $\lambda=492 \mathrm{~nm}$, which is proportional measure to the number of viable cells in wells.

\section{Trypan blue dye exclusion assay}

Proliferation and viability was confirmed by trypan blue $0.1 \%$ exclusion method [29]. A fixed number of cells were seeded onto 6 wells plates with $2 \mathrm{~mL}$ of medium for 24 hrs. Then, culture medium was changed by nonsupplemented medium to equilibrate cell cycle in $\mathrm{G}_{0} / \mathrm{G}_{1}$ phase. After $12-24 \mathrm{hrs}$, cells were incubated at $37^{\circ} \mathrm{C}$ and $5 \% \mathrm{CO}_{2}$ with solution containing each compound as experimental condition described. After $72 \mathrm{hrs}$, the cells were detached using trypsin/EDTA and centrifuged at $500 \mathrm{xg}$ for $15 \mathrm{~min}$. The cells were vigorously resuspended 
in $1 \mathrm{~mL}$ of medium. The number of cells was estimated in a mixture of $10 \mu \mathrm{L}$ of cell suspension plus $90 \mu \mathrm{L}$ of $0.4 \%$ trypan blue [dilution factor (DF) 1:10] by $5 \mathrm{~min}$, then $20 \mu \mathrm{L}$ of this mixture was placed in the hemocytometer and observed under light microscopy. All cells in central quadrant and four quadrants of corners were counted. Cells number was estimated and the viability was determined (considering that only dead cells capture the dye) using the equations previously described [30].

\section{Statistical analysis}

Values reported for all data are means \pm SE. The statistical significance of differences between means was determined by an unpaired two-tailed Student's $t$-test. Differences were considered to be significant as $p<0.05$. The parameters $\log \mathrm{IC}_{50} \pm \mathrm{SE}$ were estimated using the GRAPH PAD ${ }^{\circ}$ program.

\section{Results and discussion}

\section{Rat ASMC proliferation in response to mitogens}

Rat ASMC were incubated by 24, 48 and $72 \mathrm{hrs}$ at $1 \times 10^{3}$ cells/well in 96 well plates to evaluate its basal proliferation and response to mitogens using MTS-PMS method as shown in Figure 1. Basal proliferation of ASMC was increased time-dependent manner being significant at 24, 48 and 72 hrs. Mitogens increased ASMC proliferation at all times of culture tested. The mitogenic effectiveness at $72 \mathrm{hrs}$ was the following: $10 \%$ $\mathrm{FBS}>5 \% \mathrm{FBS}=\mathrm{EGF}(10 \mathrm{ng} / \mathrm{mL})=$ TNF $-\alpha 10 \mathrm{ng} / \mathrm{mL}(\mathrm{n}=5$, $p<0.05)$. In addition, EGF and TNF- $\alpha$, showed a dual effect increasing ASMC proliferation reaching maximum effect at $10 \mathrm{ng} / \mathrm{mL}$ and higher concentration the proliferation effect decreased (data not shown).

Viability and cell proliferation were also evaluated by trypan blue dye exclusion method as shown in Figure 2. In these assays, ASMC were culture in 6 well plates at $2 \times 10^{5}$ cells/well and mitogens as FBS, EGF, TNF- $\alpha$, which stimulated ASMC proliferation. However, there was not a clear cut correlation between cell viability with cell proliferation. In this sense, TNF- $\alpha(10 \mathrm{ng} / \mathrm{mL})$ increased cell proliferation but decreased cell viability $(\mathrm{n}=5, \mathrm{p}<0.05)$, indicating that TNF- $\alpha$ induces cell division and also promotes cell death (apoptosis). The mechanism of cell death induced by TNF- $\alpha$ could not be assessed with the methodology here applied.

ASMC proliferation has been studied for in several conditions using various experimental animal and human models. Fetal Bovine Serum (FBS) is a potent mitogenic, that effect has been explained by the Reactive oxygen species (ROS) generation [31]. Thus, exposing normal ASMC to FBS induced proliferation, which can trigger signal transduction leading to gene expression [32,33]. $\mathrm{H}_{2} \mathrm{O}_{2}$ treatment of airways myocytes successively stimulates the MAP kinase superfamily members, which are important

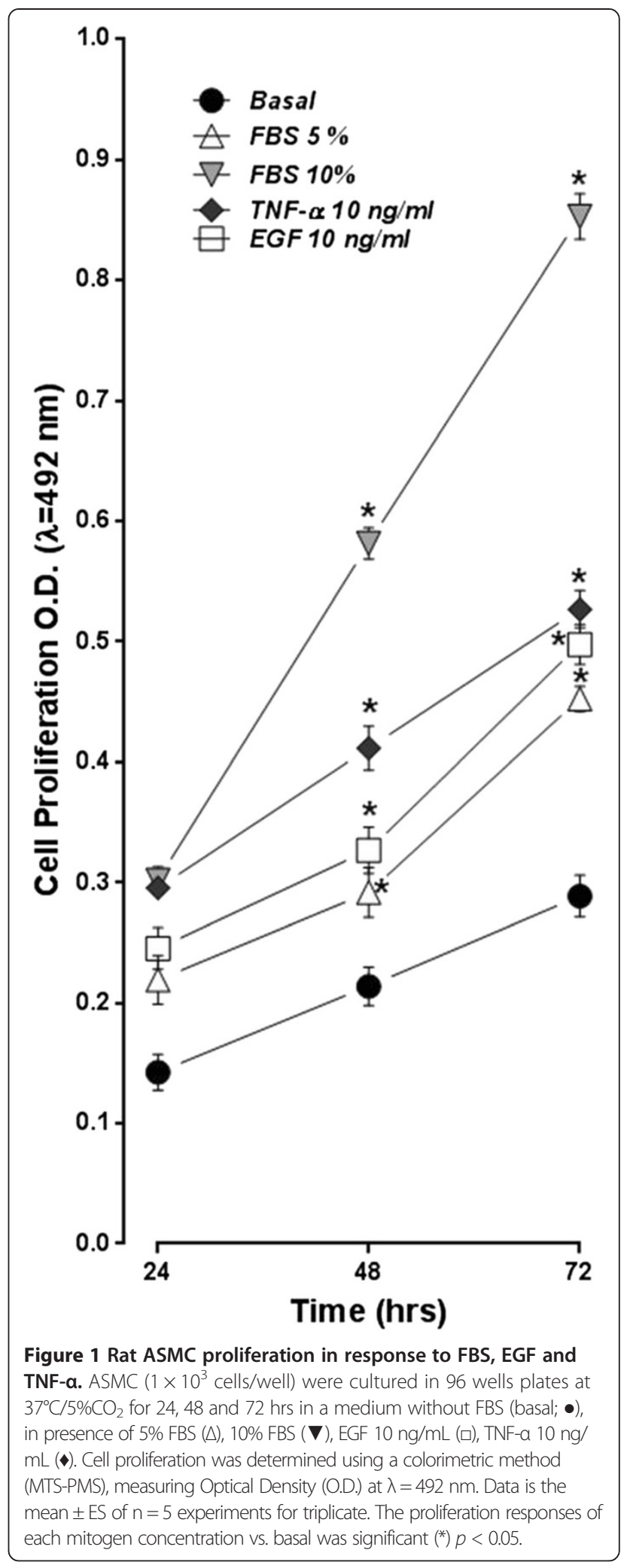

in transduction of mitogenic signals to the nucleus [34]. This has important implications for the pathogenesis of remodeling in the asthmatic airways, where myocytes are 


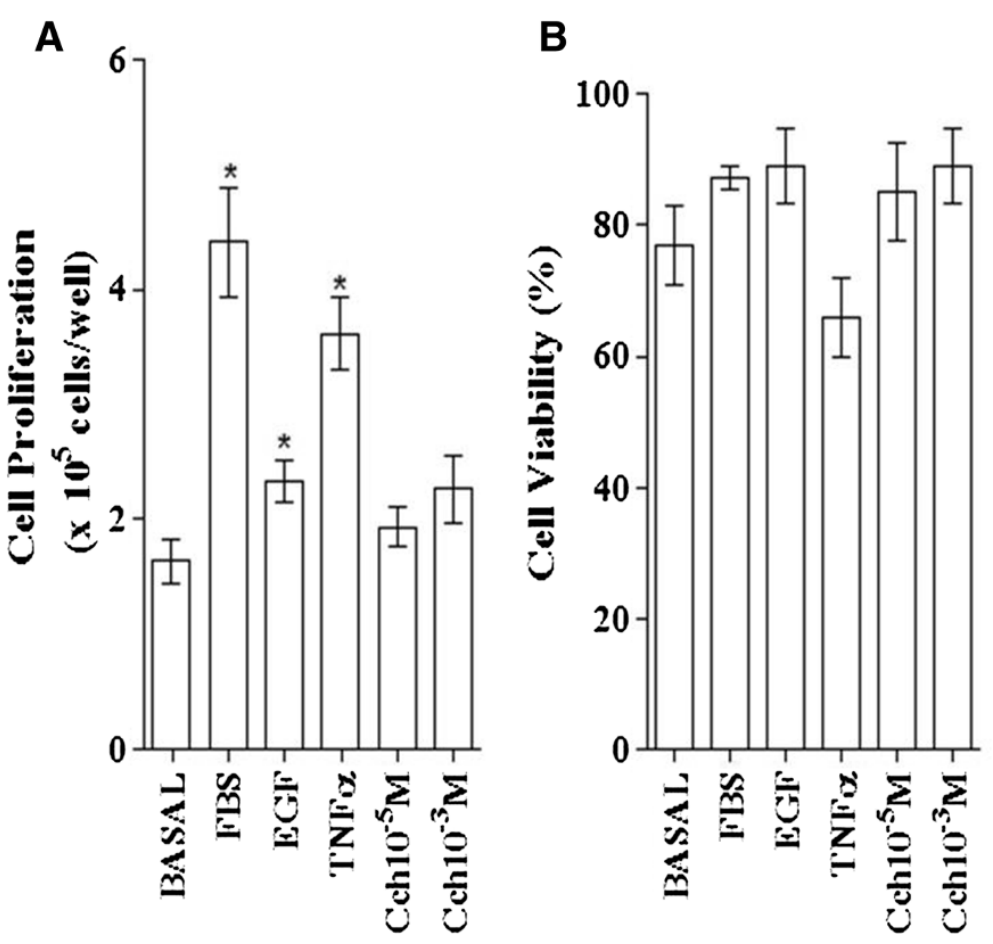

Figure 2 Rat ASMC proliferation (A) and viability (B) in presence of mitogens and Cch. ASMC $\left(2 \times 10^{5}\right.$ cells/well) were cultured in 6 wells plates at $37^{\circ} \mathrm{C} / 5 \% \mathrm{CO}_{2}$ for 48 hrs in presence of DMEM/F-12 medium (basal), 10\% FBS, EGF $10 \mathrm{ng} / \mathrm{mL}$, TNF-a $10 \mathrm{ng} / \mathrm{mL}$ and Cch $10^{-5,-3} \mathrm{M}$. Cell proliferation and viability were determined using Trypan blue dye exclusion method. Data is the mean \pm ES of $n=5$ experiments for triplicate. The proliferation responses of each mitogen concentration vs. basal was significant $\left(^{*}\right) p<0.05$.

exposed to ROS from activated eosinophils/neutrophils and macrophages that are present during the acute and chronic inflammation process presents in asthma and COPD. In addition, even serum can leaks from vascular capillary system as a consequence of submucosal edema and increased submucosal vascular permeability in asthma [35]. In our experiments, FBS was the best mitogen for rat ASMC, which confirmed the biological actions previously reported.

Another mitogen studied was Tumor necrosis factor (TNF- $\alpha$ ), which is a potent proinflammatory cytokine and its role as a potential mediator in asthma has been well described [36,37]. Moreover, TNF- $\alpha$ has been reported to be a poor mitogen and it can also modulate cultured ASM cells to proliferate [38,39]. In our study, these reported biologic actions of TNF- $\alpha$ on rat ASMC were confirmed.

EGF is a mitogen that been reported to stimulate ASMC growth in vitro [40] and this growth factor has been shown to be upregulated in asthmatic human airways [41]. In our work, we found that EGF was able to stimulate rat ASMC proliferation and confirmed the reported findings. In summary, both TNF- $\alpha$ and EGF displayed similar mitogenic activity in rat ASMC. In addition, both mitogens exhibited a dual effect on ASMC proliferation.

\section{Muscarinic agonist (Cch) modulates rat ASMC proliferation}

The effects of muscarinic antagonists AF-DX-116 and 4-DAMP on this Cch modulation

Rat ASMC were incubated by 24, 48 and $72 \mathrm{hrs}$ at $1 \times 10^{3}$ cells/well in 96 well plates with increasing doses of Cch in the presence and absence of 10\% FBS (Figure 3). Basal proliferation increased, in a dose dependent manner by Cch, being significant at 24 and $48 \mathrm{hrs}(\mathrm{n}=6, p<0.05)$ (Figure 3). However, Cch, decreases the ASMC proliferation induced by $10 \%$ FBS (Figure 3). Thus, a dosedependent inhibitory effect on ASMC proliferation by Cch was significant at 48 and 72 hrs. Proliferation inhibition was not due to death cell because ASMC viability in presence of Cch was confirmed with blue dye exclusion method (Figure 2).

To further evaluate the modulation properties of Cch on ASCM proliferation, it was found that, at $24 \mathrm{hrs}$, Cch stimulated cell proliferation and synergistically potentiated the mitogenic effect of 5\% FBS and a similar trend was observed with EGF $5 \mathrm{ng} / \mathrm{mL}(\mathrm{n}=6, p<0.05)$ (Figure 4). Nonetheless, the Cch inhibitory effect was observed with EGF $10 \mathrm{ng} / \mathrm{mL}$ and TNF- $\alpha 10 \mathrm{ng} / \mathrm{ml}$ being significant $(\mathrm{n}=6, p<0.05)$ (Figure 4).

To determine the MAchR subtype involved in these opposite effects displayed by Cch. ASMC at $1 \times 10^{3}$ cells/ 


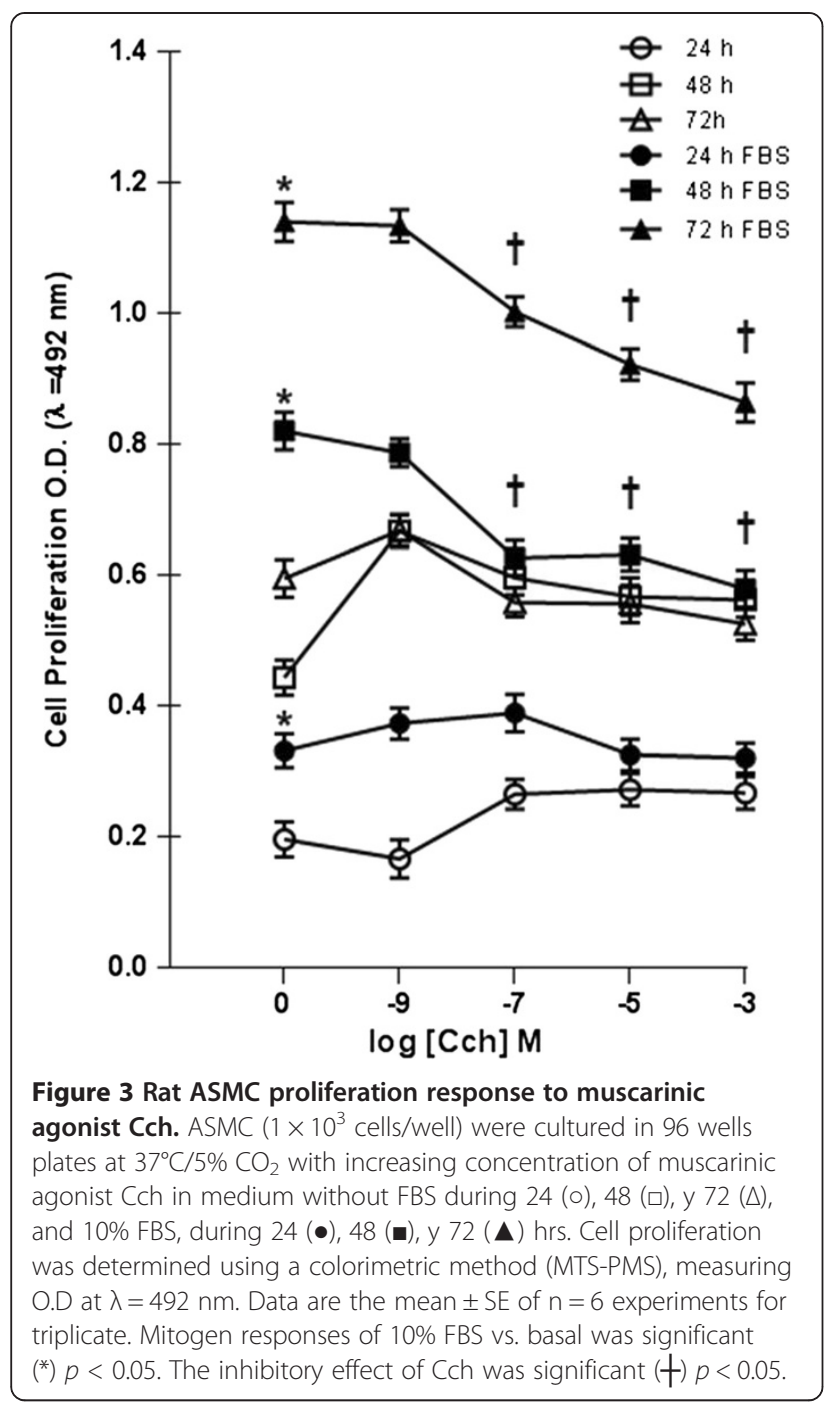

well were incubated in 96 well plates in the presence of $5 \% \mathrm{FBS}$ and 5\% FBS plus Cch leading to a rise in cell proliferation as exhibited in Figure 5. Under these experimental conditions, ASMC were exposed to increasing concentrations of preferential muscarinic antagonist 4-DAMP (for $\mathrm{M}_{3} \mathrm{AChR}$ ) and AF-DX-116-DS (for $\mathrm{M}_{2} \mathrm{AChR}$ ) as shown in Figure 5A. These muscarinic antagonists reversed both, the 5\% FBS induced proliferation activity and the Cch-induced proliferation $(\mathrm{n}=4$, $p<0.05)$ as shown in Figure 5A. Unexpectedly, the 5\% FBS induced proliferation was inhibited by these muscarinic antagonists displaying, the $\log \mathrm{IC}_{50}$ for 4-DAMP and AFDX-116, which were similar as 4-DAMP + FBS $=-7.34$ \pm 0.21 AFDX-116 + FBS $=-7.26 \pm 0.51$. These results may be explained by some inverse agonist actions described by these muscarinic drugs [42]. This experimental findings may be a research subject in the future.

Interestingly, in the case of the synergistic Cch and FBS proliferation effect, both muscarinic antagonists

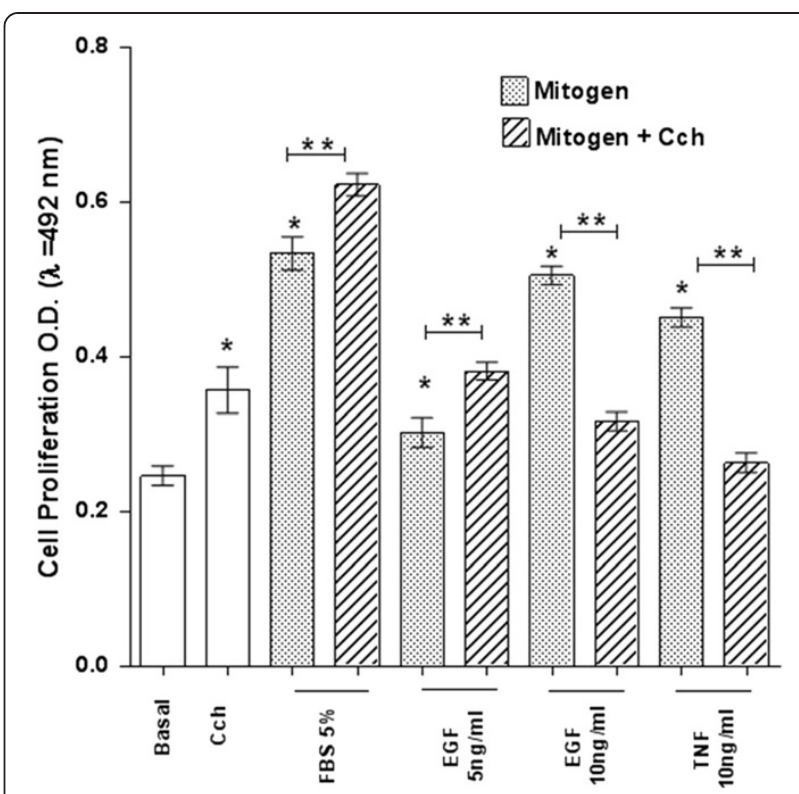

Figure 4 Rat ASMC proliferation in response to Cch and mitogens. ASMC $\left(1 \times 10^{3}\right.$ cells/well) were cultured in 96 wells plates at $37^{\circ} \mathrm{C} / 5 \% \mathrm{CO}_{2}$ with DMEM/F-12 medium (basal), CCh $10^{-3} \mathrm{M}, 5 \%$ FBS, EGF 5 and $10 \mathrm{ng} / \mathrm{mL}$, and TNF-a $10 \mathrm{ng} / \mathrm{mL}$ during $24 \mathrm{hrs}$. Cell proliferation was determined using a colorimetric method (MTS-PMS), measuring O.D at $\lambda=492 \mathrm{~nm}$. Data is the mean \pm ES of $n=6$ experiments for triplicate. Each mitogen proliferation responses vs basal was significant $\left(^{*}\right) p<0.05$. Moreover, significant differences $\left.{ }^{* *}\right) p<0.05$ between mitogen vs mitogen plus Cch condition were found.

were able to inhibit such proliferation activity displaying different values of the $\log \mathrm{IC}_{50}$ for the 4-DAMP + FBS + $\mathrm{Cch}=-7.38 \pm 0.42$ and AFDX-116 + FBS $+\mathrm{Cch}=-8.99 \pm$ 0.45 . From these data, there is two order of magnitude of difference between these values supporting a pharmacological profile that AFDX $116>4$-DAMP, that belongs to an $\mathrm{M}_{2}$ AchR.

Trying to understand this novel finding on the ability of Cch to exhibit anti-proliferative properties especially at high mitogen concentration (10\% FBS). It was found, this anti-mitogenic Cch effect was reversed, in a dosedependent manner, by preferential muscarinic antagonists as AF-DX-116 ( $\mathrm{M}_{2} \mathrm{AChR}$ antagonist), which was more efficient than 4-DAMP $\left(\mathrm{M}_{3} \mathrm{AChR}\right.$ antagonist) to reverse this novel Cch inhibition activity as shown in Figure 5B. The proliferative stimulatory responses displayed by muscarinic antagonists reversed significantly the anti-mitogenic Cch $\left(1 \times 10^{-5} \mathrm{M}\right)$ action $(p<0.05)$. Thus, the $\log \mathrm{IC}_{50} \pm \mathrm{SE}$ were 4-DAMP $=-7.11 \pm 0.71$ and AFDX- $=-9.40 \pm 0.37$ were estimated. The difference between these $\log \mathrm{IC}_{50}$ values is more than 2 orders of magnitude, that support a pharmacological profile is AFDX $116>>$ 4-DAMP clearly belongs to an $\mathrm{M}_{2}$ AchR .

It important to point out that all Cch effects here described on rat ASMC proliferation were affected by 

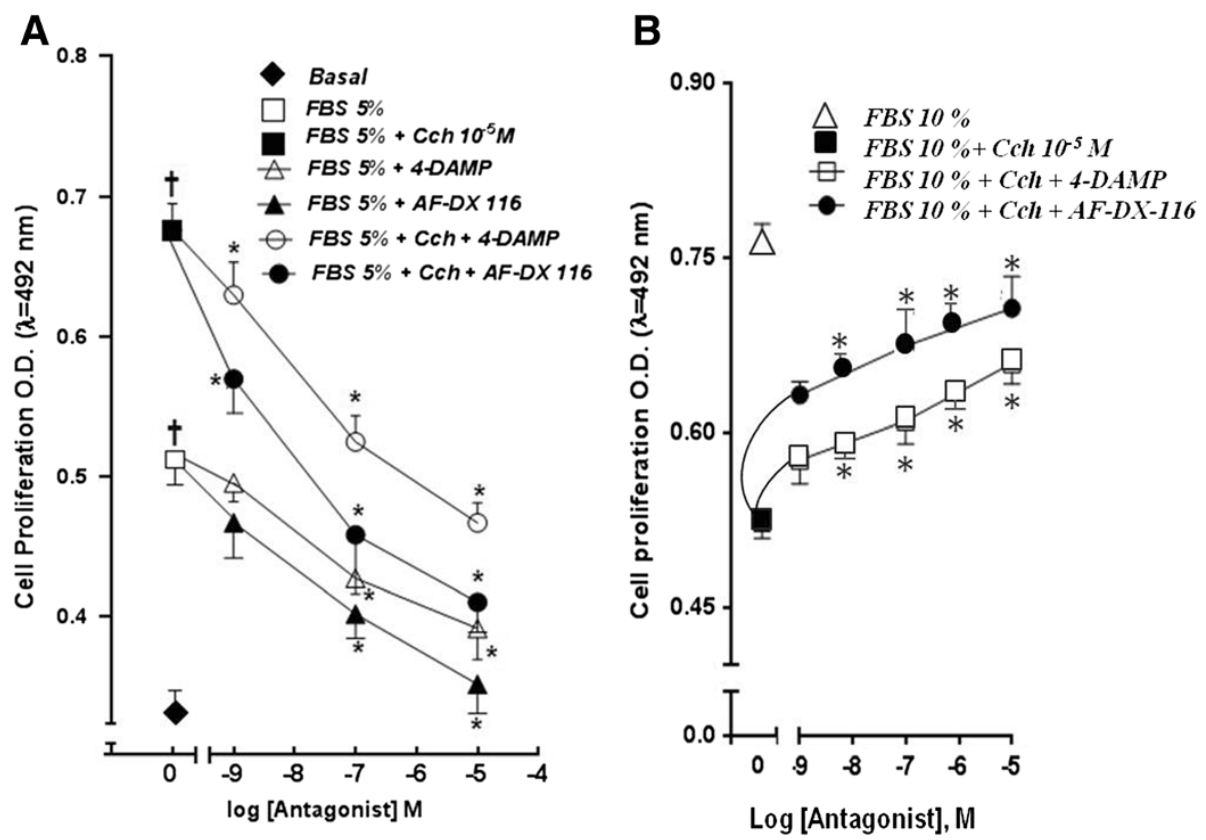

Figure 5 Effect of selective muscarinic antagonists AF-DX-116 $\left(M_{2} A C h R\right)$ and 4-DAMP $\left(M_{3} A C h R\right)$ on ASMC proliferation at 5 and $10 \%$ FBS. A. Effect of increasing concentration of AF-DX-116 and 4-DAMP on the synergistic effect induced by Cch in presence of 5\% FBS. ASMC (1× 10 cells/well) were cultured in 96 wells plates for 72 hrs. Cell proliferation was determined using a colorimetric method (MTS-PMS), measuring O.D at $\lambda=492 \mathrm{~nm}$. ( $n=5$, for triplicate). The synergistic proliferation responses in the presence of $5 \% \mathrm{FBS}$ and Cch $\left(1 \times 10^{-3} \mathrm{M}\right)$ plus $5 \% \mathrm{FBS}$ against basal condition were significant different $(+) p<0.05$. The muscarinic antagonists inhibitory responses were significant against the " 0 " Cch condition $\left(^{*}\right) p<0.05$. The estimated Log IC $50 \pm$ SE were 4-DAMP + FBS $=-7.34 \pm 0.21 ; 4-\mathrm{DAMP}+\mathrm{FBS}+\mathrm{Cch}=-7.38 \pm 0.42 ; \mathrm{AFDX}-116+\mathrm{FBS}=-7.26 \pm 0.51$ and AFDX-116 + FBS $+C$ Ch $=-8.99 \pm 0.45$. B.- Effect of increasing concentrations of AF-DX-116 and 4-DAMP on the anti-proliferative effect induced by Cch $\left(1 \times 10^{-5} \mathrm{M}\right)$, in presence of $10 \% \mathrm{FBS}$. ASMC $\left(1 \times 10^{3}\right.$ cells/well) were cultured in 96 wells plates for $72 \mathrm{hrs}$. Cell proliferation was determined using a colorimetric method (MTS-PMS), measuring O.D at $\lambda=492 \mathrm{~nm}$. ( $n=5$, for triplicate). The muscarinic antagonists stimulatory proliferative responses were significant $\left.{ }^{*}\right) p<0.05$ against the anti-proliferative $C c h\left(1 \times 10^{-5} \mathrm{M}\right)$. The estimated Log $\mathrm{IC}_{50} \pm \mathrm{SE}$ were $4-\mathrm{DAMP}=-7.11 \pm 0.71$ and AFDX- $=-9.40 \pm 0.37$.

muscarinic antagonists, which supported the rationale that these mitogenic and anti-mitogenic effects are mediated, via muscarinic receptors, and nor through nicotinic receptors, which may be affected by Cch.

Interestingly, in our study model rat ASMC, muscarinic agonist, Cch, displayed three distinct effects on ASMC proliferation: 1) stimulatory effect by itself, 2) synergistic effect, at low concentrations of mitogens (5\% FBS, EGF $5 \mathrm{ng} / \mathrm{mL}$ ), and 3) inhibitory effect, at maximum concentration of mitogens (10\% FBS, $10 \mathrm{ng} / \mathrm{mL}$ of EGF or TNF- $\alpha$ ) as above described.

It is complex matter to explain these diverse biological effects that are initiate by the binding of a neurotransmitter (ACh) to muscarinic receptors (GPCR) at sarcolema of ASMC, with the involvement of some intracellular seconds messengers (cGMP, cAMP, $\mathrm{Ca}^{2+}$ ) that trigger several intracellular signal cascades that cross-talk involving protein-protein interactions and reversible posttranslational modifications (phospho/dephosphorylation processes) to activate or regulate the nuclear factors involve in the DNA duplication and cell division, which is a fast growing research field in the last 20 years.
Neuronal and non-neuronal $\mathrm{ACh}$, has been proposed to promote airway remodeling and increased smooth muscle thickening and airway hyperresponsiveness development in asthma models, which was prevented by a specific antagonist of $\mathrm{M}_{3} \mathrm{AChR}$ such as tiotropium bromide $[19,43]$. Classically, it has been claimed that agonist muscarinic stimulation "in vitro" is not sufficient to induce ASMC proliferation and only in combination with growth factors, the mitogenic effect was observed $[19,21,23]$. In this sense, we found a stimulatory effect on rat ASMC proliferation by Cch, which was less potent than FBS, EGF and TNF- $\alpha$. Muscarinic stimulation has been associated with MAPK and PI3-K activation [19-21]. Moreover, ERKs activation and phosphorylation is reaching in response to agonist of $M_{2} A C h R$ and $M_{3} A C h R$. The $M_{3} A C h R$ pathway is linked to a $G_{\mathrm{q}}$ protein mediated and dependent of Raf-1 phosphorylation by $\mathrm{PKC}$, whereas $\mathrm{M}_{2} \mathrm{AChR}$ pathway is $\mathrm{G}_{\mathrm{i} / \mathrm{o}}$ protein mediated and depends on PI3-K activation [43]. However, in human and bovine ASMC, MAChR proliferative activation as well as others GPCRs requires a growth factor to activate MAPK in sustained manner $[17,43]$. Thus, gene transcription associated with cell 
cycle promotion is not sufficient to enable the transition $\mathrm{G}_{0}$ phase to $\mathrm{G}_{1}$ phase.

Muscarinic agonist synergistic effect on rat ASMC proliferation in the presence of low doses of EGF and $5 \%$ FBS was observed. The co-administration of muscarinic agonists with EGF in human ASMC induces a synergistic proliferative stimulus. This effect was associated with sustained activation of p70 S6 kinase [21,44], an effect mediated by Gq derived GBy subunits that activate phosphatidylinositol-3-kinase (PI3K) in concert with the EGF receptor $[19,44]$. In line with these findings, muscarinic receptor agonists induce an increase in proliferation of airway smooth muscle cells in combination with platelet-derived growth factor (PDGF), which is mediated by Gq-protein-coupled $\mathrm{M}_{3} \mathrm{AChR}$ and appears to involve a synergistic inhibitory phosphorylation of glycogen synthase kinase-3 (GSK-3) [45].

Similar synergistic effects of muscarinic agonists in human and bovine ASMC are antagonized by 4-DAMP and DAU 5884, in consequence appears to be $\mathrm{M}_{3} \mathrm{AChR}$ mediated [19]. However, our data obtained from rat ASMC incubated with preferential muscarinic antagonists AF-DX-116 (for $\mathrm{M}_{2} \mathrm{AChR}$ ) [46] and 4-DAMP (for $\mathrm{M}_{3} \mathrm{AChR}$ ) suggest that synergistic effect is mediated through the activation of $\mathrm{M}_{2} \mathrm{AChR}\left(\log \mathrm{IC}_{50}\right.$ AF-DX-116 < $\mathrm{IC}_{50}$ 4-DAMP). Our results suggest that constitutive activity of $\mathrm{M}_{2} \mathrm{AChR}$ could be necessary to maintain ASMC proliferation in $5 \% \mathrm{FBS}$ response. Additionally, $\mathrm{M}_{2} \mathrm{AChR}$ is coupled to a pertussis toxin (PTX) sensitive $G_{i / o}$ protein. Consequently, in several studies have been reported that mitogenic effect of Cch on human ASMC is antagonized by PTX $[47,48]$. To explain these synergists effects, a PTX sensitive signal cascade involving p21Ras and MAPK activation induced by muscarinic agonists may be consider [49] as reported, in vascular smooth muscle cells, where PTX treatment decreased basal proliferation and response to FBS and PDGF [50]. Interestingly, growth factors induce activation and dissociation of heterotrimeric $G$ proteins in many cell types, either through direct $\left(E G F \rightarrow G_{i / o}, G_{s}, P D G F \rightarrow\right.$ $\mathrm{G}_{\mathrm{i} / \mathrm{o}}$ ) or indirectly interaction (PDGF/EDG1 $\rightarrow \mathrm{G}_{\mathrm{i} / \mathrm{o}}$ ) [51]. Src and PI3-K activation by PDGF in bovine ASMC is mediated by a PTX-sensitive G protein [52]. Therefore, it is possible that $\mathrm{M}_{2} \mathrm{AChR} / \mathrm{G}_{\mathrm{i} / \mathrm{o}}$ protein/p21Ras and MAPK signal cascade in response to Cch might be more efficient to potentiate the signal transduction of growth factors present in FBS. Nonetheless, synergistic effect of muscarinic agonists may involve a sustained activation of $\mathrm{p} 70^{\mathrm{S} 6 \mathrm{~K}}$ in promotion of protein synthesis related with cell cycle transition $[21,44]$ rather than increased of MAPK activation [44]. Moreover, glycogen synthase kinase-3 $\beta$ (GSK-3 $\beta$ ) could be another possible mediator due to it has been involved in methacholine (muscarinic agonist) synergism on human ASMC proliferation. Thus, an active form of GSK$3 \beta$ (dephosphorylated) inhibits cell proliferation through negative regulation of some mitogenic promoters such as cyclin D1 accumulation in cell nucleus [45].

Briefly, muscarinic agonist synergism with other mitogens on rat ASMC proliferation could be mediated by interactions between several pathways and signal transduction effectors as GSK-3 $\beta, \mathrm{p} 70^{\mathrm{S} 6 \mathrm{~K}}$ and ERKs. During the preparation of this manuscript, it was reported that muscarinic agonists (metacholine) exhibits synergistic effects on TGF- $\beta 1$-induced proliferation, which were reduced by tiotropium and the $\mathrm{M}_{2} \mathrm{AChR}$ subtype antagonist gallamine, but not the $\mathrm{M}_{3} \mathrm{AChR}$ antagonist DAU5884. Moreover, pertussis toxin treatment also prevented the potentiation of TGF- $\beta 1$-induced proliferation by methacholine, via an $\mathrm{M}_{2} \mathrm{AChR}$ coupled to $\mathrm{Gi} / \mathrm{o}$ protein. These authors concluded that exposure to TGF- $\beta 1$ induces ASMC proliferation, which is enhanced by $\mathrm{M}_{2} \mathrm{AChR}$ stimulation [53]. These explanations on the role of $\mathrm{M}_{2} \mathrm{AChR}$ are similar to the ones here described for rat ASMC.

Muscarinic agonist inhibition of rat ASMC proliferation is an original experimental finding of this work. This effect was observed when ASMC were incubated with Cch plus mitogens at its maximum doses for proliferation responses such as $10 \%$ FBS. This inhibitory novel response seems to be also mediated by $\mathrm{M}_{2} \mathrm{AChR}$ from pharmacological profile responses $\left(\log \mathrm{IC}_{50} \mathrm{AF}-\mathrm{DX}-116<\log \mathrm{IC}_{50} 4\right.$-DAMP).

Muscarinic agonist inhibition mechanism may be the result of the activation of two signaling pathways: 1) The cGMP/PKG activation cascade [54-58], and 2) MAPK activation: p38 MAPK and JNK cascade [11]. Increased cGMP production by muscarinic agonist (Cch) has been reported previously in bovine tracheal smooth muscle [54-56]. Transduction mechanisms proposed include MAchR stimulation, G protein activation and subsequent activation of NO-sensitive-soluble guanylyl cyclase (NO-sGC) and/or membrane-spanning Natriuretic Peptide Receptor guanylyl cyclase (NPR-GC). Recently, we have described a $M_{2} A C h R$ coupled to a $G_{i / o}$ protein-dependent process, that augmented NO-sGC activity in bovine smooth muscle, independently of nitric oxide $(\mathrm{NO})[54,56]$. Likewise, $\mathrm{M}_{3} \mathrm{AChR} / \mathrm{G}_{\mathrm{q}}$ protein complexes have been associated with the NPR-GC-B activation $[54,56]$ producing cGMP, which can activate PKG. This last nucleotide-dependent kinase can phosphorylate transcription factors associated with inhibition of gene expression that promote cell cycle, also induce increment of proteins that leads cell cycle arrest as $\mathrm{p} 21^{\text {Cip } 1 / \text { Waf1 }}$ [58].

The involvement of these two GCs (sGC and/or NPRGC-B) in rat ASMC in response to Cch is supported by some additional experimental evidences (data not shown): 1) Cch induced proliferation is blocked by sodium nitroprusside (SNP; NO donor). 2), Cch blocked synergistic effect on ASMC proliferation induced by ODQ, a selective inhibitor of NO-sGC, and 3) Cch potentiates the inhibitory 
effect of natriuretic peptide type-C (CNP; activator of NPR-GC-B) on ASMC proliferation. All these additional data suggest that inhibitory effect of Cch on mitogen-induced ASMC proliferation could include the activation of ones of these cGMP-dependent signaling pathways above mentioned. The identification of the members of the cGMP-PKG cascades related to this $\mathrm{M}_{2} \mathrm{AChR}$-dependent inhibitory effect on ASMC proliferation is under intense investigation in our laboratory.

The fact that ASMC proliferation inhibition by Cch was observed at high doses of mitogens leads to ask whether inhibition is due to certain level of mitogenic pathways activation, which are associated in parallel with anti-proliferative pathway facilitation (e.g. $\uparrow[\mathrm{cGMP}]_{\text {int }}$ ) or mitogenic pathways over-activation (e.g. p38MAPK or JNK) trigger cell death $[11,59]$. Inhibition of cell proliferation by muscarinic agonists has been reported in ovarian cells [46], NIH3T3 cells [60], and cancer cells [61], in most cases $\mathrm{M}_{3} \mathrm{AChR}$ and p21 ${ }^{\text {Cip1 Waf1 }}$ expression was involved in cell cycle arrest. The dual effects of Cch on proliferation have also been reported for others cell systems [62].

ASMC phenotype present in these assays may be another factor that can influence these results. ASMC express both $\mathrm{M}_{2} \mathrm{AChR}$ and $\mathrm{M}_{3} \mathrm{AChR}$, in a proportion that depends of species and cell phenotype. In ASMC with contractile phenotype predominates $\mathrm{M}_{3} \mathrm{AChR}$ expression ( $80 \%$ ) [37]. Prolonged serum deprivation induces $\mathrm{M}_{3} \mathrm{AChR}$ transcription and expression in ASMC that express contractile proteins and generate a basal lamina rich in laminina. Airway remodeling models suggest that $\mathrm{M}_{3} \mathrm{AChR}$ mediated $\mathrm{ACh}$ effects "in vivo" [17-20]. Chronic activation of $\mathrm{M}_{3} \mathrm{AChR}$ may constitute an "in vivo" mechanism for ASMC phenotype modulation, which is crucial event in tissue remodeling rather proliferation stimulation $[18,28]$. By other hand, ASMC with synthetic-proliferative phenotype express mainly $M_{2} A C h R$ [63], which seem to be our case. Therefore, cell population used in this work was heterogeneous in similar manner to ASMC "in vivo" [7]. Thus, the $\mathrm{M}_{2} / \mathrm{M}_{3} \mathrm{AChR}$ ratio is $4: 1$, which has been described in intact airway smooth muscle cells $[64,65]$.

The exact cellular mechanisms underlying MAChRmodulated DNA synthesis and ASMC proliferation are not fully understood. ASMC proliferation involves several intracellular pathways leading to DNA replication and cell division as above discussed. In relation to this novel inhibitory effect of muscarinic agonists here described may improve our understanding of the intracellular mechanisms underlying the activation of mitogenic and anti-mitogenic pathways and provide insights for therapeutic drug development. Recent evidence suggests that ACh acting through muscarinic receptors may play an inhibitory role in the airway remodeling. The anticholinergic drug tiotropium bromide, which selectively antagonizes the $\mathrm{M}_{3} \mathrm{AChR}$ subtype, could be beneficial in attenuating airway remodeling in chronic asthma [66]. These authors reported that in murine (BALB/c mice) models of chronic asthma, sensitized and challenged to ovalbumin, the expression of the $\mathrm{M}_{3} \mathrm{AChR}$ was inhibited and the $\mathrm{M}_{2} \mathrm{AChR}$ was elevated by the administration of tiotropium bromide. Our results on the role of $\mathrm{M}_{2} \mathrm{AChR}$ inhibiting the mitogen-induced proliferation may be relevant, which may be similar environment to the ones present in chronic asthma, which can explain these interesting experimental results of tiotropium bromide on $\mathrm{M}_{3} / \mathrm{M}_{2} \mathrm{AChR}$ expression [66].

\section{Conclusions}

Muscarinic agonist has three effects on "in vitro" rat ASMC proliferation: 1) stimulation, 2) synergism, and 3) inhibition. Interestingly, both biological actions seem to be mediated by $\mathrm{M}_{2} \mathrm{AChRs}$ through activation of distinctive and multiple signal transduction pathways, which may depend on the cell phenotype and the type and mitogen concentration used. These findings are important in ASMC proliferation induced by ACh "in vivo" especially on cells with synthetic-proliferative phenotype. If, mitogenic and anti-mitogenic effects are both mediated by the same receptor, leads us to propose an ASMC proliferation modulation by $\mathrm{ACh}$, via $\mathrm{M}_{2} \mathrm{AChRs}$. Our data here reported support the rationale about the need for the developing of new muscarinic antagonists-derivated from tiotropium bromide or similar compound that preferentially antagonize the putative $M_{3} A C h R$ involves in the mitogen-induced ASMC proliferation associated to the airway remodeling presents in chronic asthma and COPD and increase the level of expression of this novel action of $\mathrm{M}_{2} \mathrm{AChR}$ acting as anti-proliferation receptor.

\section{Abbreviations}

ACh: Acetylcholine; ASMC: Airway smooth muscle cells; Cch: Carbamylcholine; COPD: Chronic obstructive pulmonary disease; CGMP: Cyclic guanosine monophosphate; EGF: Epidermal growth factor; EGFR: EGF Receptor extracellular signal-regulated kinases; ERKs: Fetal bovine serum; FITC: Fluorescein-1-isothiocyanate-conjugated; GPCR: G protein-coupled receptors; GSK-3 $\beta$ : Glycogen synthase kinase-3 $\beta ; I_{50}$ : half maximal inhibitory concentration; MAPK: Mitogen-activated protein kinases; mAchR: Muscarinic receptors; OD: Optical density; NO: Nitric oxide; NPR-GC: Natriuretic peptide receptor sensitive guanylyl cyclase; PDGF: Platelet-derived growth factor; PTX: Pertussis toxin; PDK-1: 3'-phosphoinositide-dependent kinase-1; PI3-K: Phosphoinositide 3-kinase; PKC: Protein kinase type C; NO-sGC: NO sensitive soluble guanylyl cyclase; TNF-a: tumor necrosis factor-alpha.

\section{Competing interests}

The authors declare that they have no competing interests.

\section{Authors' contributions}

FPU, CAFA, RFR, RGA, ILB, MJA. FPU, CAFA and RFR participated in the design and performance of tissue cell cultures and proliferation assays. FPU and MJA participated in the design of the study and performed the statistical analysis. FPU and MJA conceived the study. RGA participated in its design and coordination and drafted the manuscript. ILB helped to draft and the final version of the manuscript. All authors read and discussed and approved the final version of this manuscript. 


\section{Authors' information}

FPU: PhD in Cell Biology. Specialist in ASCM and MAPK expert. Actually is a Assistant professor at Biomembranes Section form Instituto de Medicina Experimental (IME). Faculty of Medicine. Central University of Venezuela (UCV).

CAFA: MD and Postgraduate at Biomembranes Section form Instituto de Medicina Experimental (IME). Faculty of Medicine. Central University of Venezuela (UCV).

RFR: MD and Postgraduate at Biomembranes Section form Instituto de Medicina Experimental (IME). Faculty of Medicine. Central University of Venezuela (UCV).

RGA: Ph D. in Biochemistry Molecular and Cell Biology from Cornell University. Actually she is Full Professor in Biochemistry Molecular and Cell Biology at Biomembranes Section form Instituto de Medicina Experimental (IME). Faculty of Medicine. Central University of Venezuela (UCV).

ILB: MD. Specialist in Biochemistry and Cell Biology from UCV. Actually she is Full Professor in Biochemistry and Cell Biology at Biomembranes Section form Instituto de Medicina Experimental (IME). Faculty of Medicine. Central University of Venezuela (UCV).

MJA: MD. \& Ph D. in Biochemistry Molecular and Cell Biology from Cornell University. Actually, he is Full Professor in Biochemistry Molecular and Cell Biology at Biomembranes Section and Director of Instituto de Medicina Experimental (IME). Faculty of Medicine. Central University of Venezuela (UCV).

\section{Acknowledgments}

This work was supported by grants from CDCH-UCV PG-09-00-7401-2008/2 to RGA, CDCH-UCV PI-09-7726- 2009/2 to ILB.

Received: 10 July 2013 Accepted: 17 December 2013

Published: 30 December 2013

\section{References}

1. Jeffery PK: Remodeling in asthma and chronic obstructive lung disease. Am J Respir Crit Care Med 2001, 164:S28-S38.

2. Elias J: Airway remodeling in asthma. Am J Respir Crit Care Med 2001, 161:S168-S171.

3. Benayoun L, Druilhe A, Dombret M-C, Aubier M, Pretolani M: Airway structural alterations selectively associated with severe asthma. Am J Respir Crit Care Med 2003, 167:1360-1368.

4. Pepe C, Foley S, Shannon J, Lemiere C, Olivenstein R, Ernst P, et al: Differences in airway remodeling between subjects with severe and moderate asthma. J Allergy Clin Immunol 2005, 116:544-549.

5. Woodruff PG, Dolganov GM, Ferrando RE, Donnelly S, Hays SR, Solberg OD, et al: Hyperplasia of smooth muscle in mild to moderate asthma without changes in cell size or gene expression. Am J Respir Crit Care Med 2004, 169:1001-1006.

6. Hirst SJ, Martin JG, Bonacci JV, Chan V, Fixman ED, Hamid QA, et al: Proliferative aspects of airway smooth muscle. J Allergy Clin Immunol 2004, 114:S2-S17.

7. Sukkar MB, Stanley AJ, Blake AE, Hodgkin PD, Johnson PR, Armour CL, et al: 'Proliferative' and 'synthetic' airway smooth muscle cells are overlapping populations. Immunol Cell Biol 2004, 82(5):471-478.

8. Naureckas E, Ndukwu I, Halayko A, Maxwell C, Hershenson M, Solway J: Bronchoalveolar lavage fluid from asthmatic subjects is mitogenic for human airway smooth muscle. Am J Respir Crit Care Med 1999, 160:2062-2066.

9. Proskocil BJ, Sekhon HS, Jia Y, Savchenko V, Blakely RD, Lindstrom J, Spindel ER: Acetylcholine is an autocrine or paracrine hormone synthesized and secreted by airway bronchial epithelial cells. Endocrinology 2004, 145:2498-2506.

10. Krymskaya V, Hoffman R, Eszterhas A, Kane S, Ciocca V, Panettieri RA Jr: EGF activates ErbB-2 and stimulates phosphatidylinositol 3-kinase in human airway smooth muscle cells. Am J Physiol Lung Cell Mol Physiol 1999, 276:L246-L255.

11. Amishima M, Munakata M, Nasuhara Y, Sato A, Takahashi T, Homma Y, et al: Expresion of epidermal growth factor and epidermal growth factor receptor immunoreactivity in the asthmatic human airway. Am Rev Respir Crit Care Med 1998, 157:1907-1912.

12. Page $K$, Hershenson M: Mitogen- activated signaling and cell cycle regulation in airway smooth muscle. Front Biosci 2000, 5:d258-d267.
13. Bazzoni F, Beutler B: The tumor necrosis factor ligand and receptor families. N Engl J Med 1996, 334(26):1717-1725.

14. Howarth PH, Babu KS, Arshad HS, Lau L, Buckley M, McConnell W, et al: Tumor necrosis factor (TNF-a) as a novel therapeutic target in symptomatic corticosteroid dependent asthma. Thorax 2005, 60:1012-1018.

15. Amrani Y, Panettieri RA Jr, Frossard N, Bronner C: Activation of the TNFa-p55 receptor induces myocyte proliferation and modulates agonist-evoked calcium transients in cultured human tracheal smooth muscle cells. Am J Respir Cell Mol Biol 1996, 15:55-63.

16. Yang CM, Luo SF, Wang CC, Chiu CT, Chien CS, Lin CC, et al: Tumor necrosis factor- $\alpha$ and interleukin- $1 \beta$-stimulated cell proliferation through activation of mitogen-activated protein kinase in canine tracheal smooth muscle cells. Br J Pharmacol 2000, 130:891-899.

17. $\mathrm{Xu}$ J, Zhong NS: The interaction of tumour necrosis factor alpha and endothelin- 1 in pathogenetic models of asthma. Clin Exp Allergy 1997 27:568-573

18. Kolahian S, Gosens R: Cholinergic regulation of airway inflammation and remodelling. J Allergy (Cairo) 2012, 681258:9.

19. Gosens R, Zaagsma J, Meurs $H$, Halayko A: Muscarinic receptor signaling in the pathophysiology of asthma and COPD. Respir Res 2006, 7:73-87.

20. Gosens R, Bromhaar MM, Tonkes A, Schaafsma D, Zaagsma J, Nelemans SA et al: Muscarinic M3 receptor-dependent regulation of airway smooth muscle contractile phenotype. Br J Pharmacol 2004, 141:943-950.

21. Gosens R, Nelemans SA, Grootte Bromhaar MM, McKay S, Zaagsma J, Meurs H: Muscarinic M3- receptors mediate cholinergic synergism of mitogenesis in airway smooth muscle. Am J Respir Cell Mol Biol 2003, 28:257-262.

22. Gosens R, Bos ST, Zaagsma J, Meurs H: Protective effects of tiotropium bromide in the pregression of airway smooth muscle remodeling. Am J Respir Crit Care Med 2005, 171:1096-1102.

23. Krymskaya VP, Orsini MJ, Eszterhas AJ, Brodbeck KC, Benovic JL, Panettier RA Jr, et al: Mechanisms of proliferation synergy by receptor tyrosine kinase and $G$ protein- coupled receptor activation in human airway smooth muscle. Am J Respir Cell Mol Biol 2000, 23:546-554.

24. Febres-Aldana C, Placeres-Uray F, Fernández-Ruiz R, González de Alfonzo R, Alfonzo MJ, Lippo de Bécemberg I: Muscarinic agonist effects on proliferation of airways smooth muscle cells is mediated by the muscarinic receptor type-2 ( $m_{2}$ AChR). Ann Allergy 2009, 103(5):3-A33. Abstract.

25. Chamley-Campbell J, Campbell GR, Ross R: The smooth muscle cells in culture. Physiol Rev 1979, 59(1):2-61

26. Hall IP, Kotlikoff M: Use of cultured airway myocytes for study of airway smooth muscle. Am J Physiol 1995, 268(1 Pt 1):L1-L11.

27. Durand-Arczynska W, Marmy N, Durand J: Caldesmon, calponin and alpha-smooth muscle actin expression in subcultured smooth muscle cells from human airways. Histochemistry 1993, 100(6):465-471.

28. Cory AH, Owen TC, Barltrop JA, Cory JG: Use of an aqueous soluble tetrazolium/formazan assay for cell growth assays in culture. Cancer Commun 1991, 3(7):207-212.

29. Ricardo R, Phelan K: Counting and determining the viability of cultured cells. J Vis Exp 2008, 16:752

30. Phillips H, Terryberry J: Counting actively metabolizing tissue cultured cells. Exp Cell Res 1957, 13:341-347.

31. Brar SS, Kennedy TP, Whorton AR, Murphy TM, Chitano P, Hoidal JR: Requirement for reactive oxygen species in serum-induced and platelet-derived growth factor-induced growth of airway smooth muscle. J Biol Chem 1999, 274:20017-20026.

32. Winyard PG, Blake DR: Antioxidants, redox-regulated transcription factors and inflammation. Adv Pharmacol 1997, 38:403-421.

33. Irani $K$, Xia $Y$, Zweier JL, Sollott SJ, Der CJ, Fearon ER, Sundaresan M, Finkel T, Goldschmidt-Clermont PJ, Goldschmidt-Clermont PJ: Mitogenic signaling mediated by oxidants in Ras-transformed fibroblasts. Science 1997, 275:1649-1652.

34. Abe MK, Kartha S, Karpova AY, Li J, Liu PT, Kuo WL, Hershenson MB: Hydrogen peroxide activates extracellular signal-regulated kinase via protein kinase $C_{\text {, }}$ Raf-1 and MEK-1. Am J Respir Cell Mol Biol 1998, 18:562-569.

35. Lam S, Leriche JC, Phillips D, Chan-Yeung M: Cellular and protein changes in bronchial lavage fluid after late asthmatic reaction in patients with red cedar asthma. J Allergy Clin Immunol 1987, 80:44-50.

36. Shah A, Church MK, Holgate ST: Tumour necrosis factor alpha: a potential mediator of asthma. Clin Exp Allergy 1995, 25:1038-1044.

37. Brightling C, Berry M, Amrani Y: Targeting TNF-alpha: a novel therapeutic approach for asthma. J Allergy Clin Immunol 2008, 121:5-10. 
38. Stewart AG, Tomlinson PR, Fernandes DJ, Wilson JW, Harris T: Tumor necrosis factor alpha modulates mitogenic responses of human cultured airway smooth muscle. Am J Respir Cell Mol Biol 1995, 12:110-119.

39. Keslacy $\mathrm{S}$, Tliba $\mathrm{O}$, Baidouri $\mathrm{H}$, Amrani $\mathrm{Y}$ : Inhibition of tumor necrosis factor-alpha-inducible inflammatory genes by interferon-gamma is associated with altered nuclear factor-kappaB transactivation and enhanced histone deacetylase activity. Mol. Pharmacol 2007, 71:609-618.

40. Tamaoka M, Hassan M, McGovern T, Ramos-Barbón D, Jo T, Yoshizawa Y, Tolloczko B, Hamid Q, Martin JG: The epidermal growth factor receptor mediates allergic airway remodeling in the rat. Eur Respir J 2008, 32:1213-1223.

41. Amishima $M$, Munakata $M$, Nasuhara $Y$, et al: Expression of epidermal growth factor and epidermal growth factor receptor immunoreactivity in the asthmatic human airway. Am J Respir Crit Care Med 1998, 157:1907-1912.

42. Dowling MR, Willets JM, Budd DC, Charlton SJ, Nahorski SR, Challiss RA: A single point mutation (N514Y) in the human M3 muscarinic acetylcholine receptor reveals differences in the properties of antagonists: evidence for differential inverse agonism. J Pharmacol Exp Ther 2006, 317:1134-1142.

43. Bos IST, Gosens R, Zuidhof AB, Schaafsma D, Halayko AJ, Meurs H, et al: Inhibition of allergen-induced airway remodelling by tiotropium and budesonide: a comparison. Eur Respir J 2007, 30:653-661.

44. Patel TB: Single transmembrane spanning heterotrimeric $G$ protein-coupled receptors and their signaling cascades. Pharmacol Rev 2004, 56(3):371-385.

45. Conway AM, Rakhit S, Pyne S, Pyne NJ: Platelet-derived-growth-factor stimulation of the p42/p44 mitogen-activated protein kinase pathway in airway smooth muscle: role of pertussis-toxin-sensitive G-proteins, c-Src tyrosine kinases and phosphoinositide 3-kinase. Biochem J 1999, 337(Pt 2):171-177.

46. Gosens R, Zaagsma J, Grootte Bromhaar M, Nelemans A, Meurs H: Acetylcholine: a novel regulator of airway smooth muscle remodelling? Eur J Pharmacol 2004, 500(1-3):193-201

47. Orsini MJ, Krymskaya VP, Eszterhas AJ, Benovic JL, Panettieri RA Jr, Penn RB: MAPK superfamily activation in human airway smooth muscle: mitogenesis requires prolonged p42/p44 activation. Am J Physiol 1999, 277:L479-L488.

48. Eglen RM, Hegde SS, Watson N: Muscarinic receptor subtypes and smooth muscle function. Pharmacol Rev 1996, 48(4):531-565.

49. Ediger TL, Toews ML: Synergistic stimulation of airway smooth muscle cell mitogenesis. J Pharmacol Exp Ther 2000, 294(3):1076-1082.

50. Billington CK, Hall IP: The effects of carbachol and PDGF-BB on DNA synthesis and the proliferation of human cultured airway smooth muscle cells. Br J Pharmacol 1998, 123:34P.

51. Winitz S, Russell M, Qian NX, Gardner A, Dwyer L, Johnson GL: Involvement of Ras and Raf in the Gi-coupled acetylcholine muscarínico M2 receptor activation of mitogen-activated protein (MAP) kinase kinase and MAP kinase. J Biol Chem 1993, 268:19196-19199.

52. Zhang LM, Newman WH, Castresana MR, Hildebrandt JD: The effect of pertussis toxin on the growth of vascular smooth muscle cells stimulated by serum or platelet-derived growth factor. Endocrinology 1994, 134(3):1297-1304.

53. Oenema TA, Mensink G, Smedinga L, Halayko AJ, Zaagsma J, Meurs H, Gosens R, Dekkers BG: Cross-talk between TGF- $\beta 1$ and muscarinic M2 receptors augments airway smoooth muscle proliferation. Am J Resp Cell Mol Biol 2013 [Epub ahead of print]

54. Billington CK, Kong KC, Bhattacharyya R, Wedegaertner PB, Panettieri RA Jr, Chan TO, et al: Cooperative regulation of p70S6 kinase by receptor tyrosine kinases and $\mathrm{G}$ protein-coupled receptors augments airway smooth muscle growth. Biochemistry 2005, 44(44):14595-14605.

55. Gosens R, Dueck G, Rector E, Nunes RO, Gerthoffer WT, Unruh H, et al: Cooperative regulation of GSK-3 by muscarinic and PDGF receptors is associated with airway myocyte proliferation. Am J Physiol Lung Cell Mol Physiol 2007, 293:L1348-L1358.

56. Bruges G, Borges A, Sánchez De Villarroel S, Lippo De Bécemberg I, Francis De Toba G, Pláceres F, et al: Coupling of M3 acetylcholine receptor to Gq16 activates a natriuretic peptide receptor guanylyl cyclase. J Recept Signal Transduct Res 2007, 27(2-3):189-216.

57. Alfonzo MJ, de Aguilar EP, de Murillo AG, de Villarroel SS, de Alfonzo RG, Borges A, et al: Characterization of a $G$ protein-coupled guanylyl cyclase-B receptor from bovine tracheal smooth muscle. J Recept Signal Transduct Res 2006, 26(4):269-297.
58. Placeres-Uray F, de Alfonzo RG, de Becemberg IL, Alfonzo MJ: Muscarinic agonists acting through $\mathrm{M} 2$ acetylcholine receptors stimulate the migration of an NO-sensitive guanylyl cyclase to the plasma membrane of bovine tracheal smooth muscle. J Recept Signal Transduct Res 2010, 30:10-23.

59. Guerra De González L, Misle A, Pacheco G, Napoleón de Herrera V, González de Alfonzo R, Lippo de Bécemberg I, et al: Effects of $1 \mathrm{H}$ - $[1,2,4]$ oxadiazolo [4,3-a] quinoxalin-1-one (ODQ) and Nomega (6) - nitro-L-arginine methyl ester (NAME) on cyclic GMP levels during muscarinic activation of tracheal smooth muscle. Biochem Pharmacol 1999, 58(4):563-569.

60. Page K, Li J, Hershenson MB: p38 MAP kinase negatively regulates cyclin D1 expression in airway smooth muscle cells. Am J Physiol Lung Cell Mol Physiol 2001, 280:L955-L964.

61. Burdon D, Patel R, Challiss RA, Blank JL: Growth inhibition by the muscarinic M (3) acetylcholine receptor: evidence for p21 (Cip1/Waf1) involvement in G (1) arrest. Biochem J 2002, 367(Pt 2):549-559.

62. Nicke B, Detjen K, Logsdon CD: Muscarinic cholinergic receptors activate both inhibitory and stimulatory growth mechanisms in NIH3T3 cells. J Biol Chem 1999, 274(31):21701-21706.

63. Williams $C L$, Lennon VA: Activation of muscarinic acetylcholine receptors inhibits cell cycle progression of small cell lung carcinoma. Cell Regul 1991, 2(5):373-381.

64. Roffel AF, Elzinga CRS, Van Amsterdam RGM, De Zeueuw RA, Zaagsma J: Muscarinic receptors in bovine tracheal smooth muscle: Discrepancies between binding and function. Eur J Pharmacol 1988, 153:73-78.

65. Misle AJ, Lippo de Bécemberg I, González de Alfonzo R, Alfonzo MJ: Methoctramine binding sites sensitive to alkylation on muscarinic receptors from tracheal smooth muscle. Biochem Pharmacol 1994, 48:191-196.

66. Kang JY, Rhee CK, Kim JS, Park CK, Kim SJ, Lee SH, Yoon HK, Kwoon SS, Kim YK, Lee SY: Effect of tiotropium bromide on airway remodeling in a chronic asthma model. Ann Allergy Asthma Immunol 2012, 109:29-35.

doi:10.1186/1939-4551-6-22

Cite this article as: Placeres-Uray et al:: M2 Muscarinic acetylcholine receptor modulates rat airway smooth muscle cell proliferation. World Allergy Organization Journal 2013 6:22.

\section{Submit your next manuscript to BioMed Central and take full advantage of:}

- Convenient online submission

- Thorough peer review

- No space constraints or color figure charges

- Immediate publication on acceptance

- Inclusion in PubMed, CAS, Scopus and Google Scholar

- Research which is freely available for redistribution

Submit your manuscript at www.biomedcentral.com/submit
C Biomed Central 